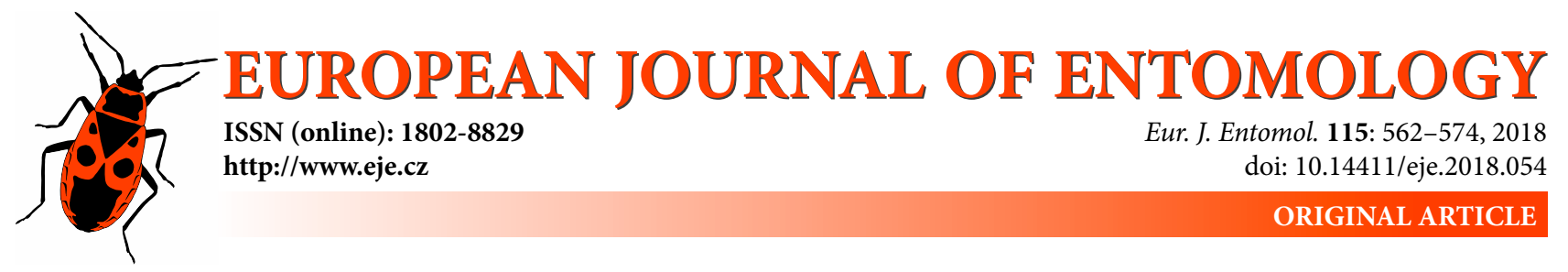

\title{
Effect of pine reforestation associated with soil disturbance on ant assemblages (Hymenoptera: Formicidae) in a semiarid steppe
}

\author{
Chema CATARINEU ${ }^{1}$, Joaquín REYES-LÓPEZ ${ }^{2}$, Joan A. HERRAIZ ${ }^{3}$ and Gonzalo G. BARBERÁ ${ }^{4}$ \\ ${ }^{1}$ Asociación de Naturalistas del Sureste (ANSE), Galdo 11, 30002 Murcia, Spain; e-mail: chema@asociacionanse.org \\ 2 Área de Ecología, Universidad de Córdoba, Edificio C-4, Celestino Mutis, Campus de Rabanales, 14071 Córdoba, Spain; \\ e-mail: cc0reloj@uco.es \\ ${ }^{3}$ Asociación Ibérica de Mirmecología (AIM), Facultat de Ciències de la Universitat de Girona, Campus de Montilivi s/n, \\ 17003 Girona, Spain; e-mail: joanaleixherraiz@gmail.com \\ ${ }^{4}$ Department of Soil and Water Conservation, CSIC-CEBAS, Campus Universitario de Espinardo, Espinardo, 30100 Murcia, \\ Spain; e-mail: gbarbera@cebas.csic.es
}

\begin{abstract}
Key words. Formicidae, interspecific competition, Mechanical Site Preparation, nest site availability, pine reforestation, soil disturbance, species richness, vegetation changes
\end{abstract}

\begin{abstract}
Soil and changes in vegetation may affect ant assemblages, but the relative importance of each in different habitats is not well characterized. In particular, information on the effects of ecological restoration on arthropods is scarce. It was decided, therefore, to study how reforestation may affect an ant assemblage. Ants were sampled in area that had been reforested and adjacent grassland using pitfall traps. Soil surface and vegetation were characterized. The disturbance of the vegetation caused by reforestation resulted in a decrease in the cover of Stipa tenacissima and Cistaceae and an increase in the cover of pine. The mechanical preparation of the site also resulted in changes in the soil surface, with an increase in the cover of stones and rocks. Ant species richness and abundance were greater at the reforested site than in the grassland and more species showed a positive than a negative response to reforestation. The underlying causes of this pattern are mainly related to changes in vegetation and structure of the soil surface and are associated with the increase in the cover of pine, which most probably provided additional food resources, and the greater cover of stones and rocks that provided more shelter for the ant assemblage.
\end{abstract}

\section{INTRODUCTION}

Grasslands dominated by esparto grass Stipa tenacissima $\mathrm{L}$. with a sparse cover of vegetation, are one of the commonest ecosystems in semiarid regions in the Western Mediterranean basin (Barberá et al., 2006; Maestre et al., 2007; Cortina et al., 2009). S. tenacissima is a perennial tussock grass in which the live biomass is usually surrounded by thick layers of standing dead grass (Maestre et al., 2007). The physiognomy of S. tenacissima grasslands is more similar to shrub land than to mesic grassland. The effect of grazing on S. tenacissima is low because this grass has a low palatability, but these grasslands have been intensively managed for producing fibre (esparto) used for making baskets, shoes, mats, etc, from prehistoric times until the 1950-1960s. Although this practice has now been mostly abandoned, the abandonment has not resulted in any major changes in the habitat (Barberá et al., 2006; Maestre et al., 2007). Many authors consider esparto grass steppes to be degraded former oak or pine open forests or shrub land dominated by, e.g., Pistacia lentiscus L. (Costa, 1973; Valdés \& Herranz, 1989; Maestre et al., 2007).

During the twentieth century, land managers in Spain promoted the planting of Pinus halepensis Mill., supposedly to boost succession. From the 1960s to 1990s most of the reforestation/afforestation in Spain was done using Mechanical Site Preparation (MSP), a broad category of site preparation typically involving the use of large heavy machinery with attached implements for preparing an area and its soil for planting trees (Löf et al., 2012). MSP causes a range of adverse effects, which are reported by different authors (Ortigosa, 1991; Chaparro \& Esteve-Selma, 1995; Ternan et al., 1996). Löf et al. (2012) state that MSP can lead to different effects on soil characteristics, such as loss of carbon, changes in the decomposition of organic matter, disturbance of nutrient pools or increase in water loss, and also an increased risk of soil erosion. MSP may increase plant biodiversity, at least temporally (Haeussler et al., 1999; Löf et al., 2012), but there are few studies on the 


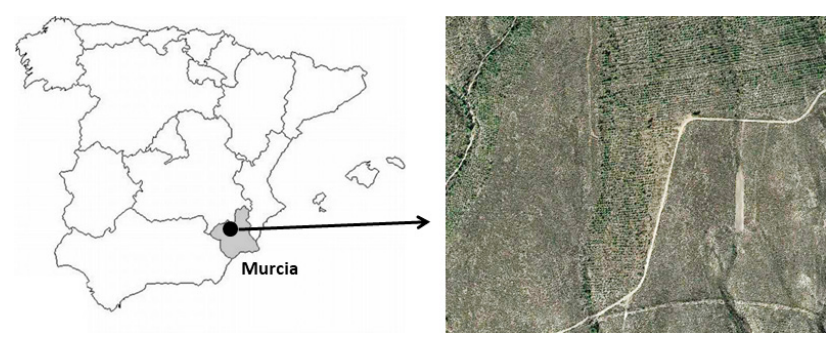

Fig. 1. Map showing the location of the study area.

effects of MSP on arthropod communities (Bellocq et al., 2001; Bird et al., 2004).

As in other arid and semi-arid areas on the Iberian Peninsula, esparto grass steppes are inhabited by a great diversity of invertebrates. Two insect groups dominate: Coleoptera (mainly Tenebrionidae) and, more specifically, Formicidae (Doblas-Miranda et al., 2007; Piñero et al., 2011). Ants are dominant organisms in terrestrial ecosystems, have very important functions, make up a great part of the animal biomass and are ecosystem engineers (Hölldobler \& Wilson, 1990; Folgarait, 1998; Read \& Andersen, 2000; Frouz \& Jilkova, 2008; Del Toro et al., 2012).

Vegetation and soil may influence ant assemblages. Shrub encroachment of grasslands results in an increase in ant diversity and/or abundance, both in mesic and semiarid grasslands (Nash et al., 2000; Bestelmeyer, 2005; Azcárate \& Peco, 2012; Wiezik et al., 2013). However, the reforestation of semiarid grasslands by pines may reduce the abundance and diversity of ants, although this effect is much lower when tree cover is sparse (Corley et al., 2006). Soil characteristics may be especially relevant to understanding ant assemblages in semiarid landscapes (Bestelmeyer \& Wiens, 2001). Nevertheless, there are very few studies and little current literature that deals with the direct and indirect effects of soil properties on ant assemblages. In the current study, MSP simultaneously disturbed both the soil and vegetation, which provided the opportunity to study the effects of both factors on ant assemblages.

We studied the effects of a 16-year old reforestation with $P$. halepensis of a semiarid S. tenacissima grassland on the local ant assemblage, looking specifically at the effects of changes in the soil and vegetation. The objectives of this study were: (i) to determine how reforestation following MSP affects the structure of the surface of the soil and vegetation; (ii) to determine how reforestation affects an epigeal ant assemblage and species, particularly their diversity and abundance; (iii) to determine which changes at the surface of the soil and in the vegetation are likely to cause changes in the ant assemblage.

\section{MATERIAL AND METHODS}

\section{Study Site}

This study was carried out in the Sierra del Picarcho (Region of Murcia, south-eastern Spain, $394 \mathrm{~m}$ a.s.1., $38^{\circ} 20^{\prime} \mathrm{N}, 1^{\circ} 29^{\prime} \mathrm{W}$; Fig. 1). Soils are mostly Petric Calcisols (FAO-ISRIC-ISSS, 1998), characterized by an A-Ckm1-Ckm2 profile, with a thick petrocalcic horizon (hardpan) at a depth of 40-70 $\mathrm{cm}$. The topography of the area is mostly flat, with slopes not exceeding 6\% (Barberá et al., 2006). The climate is semiarid Mediterranean. At the nearby

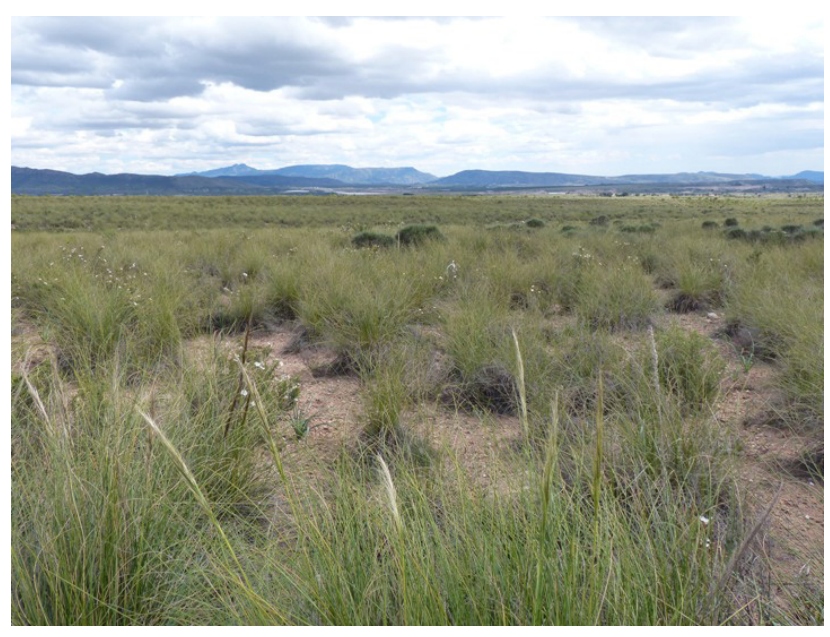

Fig. 2. Steppe grassland at the study site.

meteorological station of La Carrichosa (6.22 km S, $254 \mathrm{~m}$ a.s.1., data 1995-2012) the following annual mean values were recorded: temperature $17.2^{\circ} \mathrm{C}$, relative humidity $64 \%$, rainfall $253 \mathrm{~mm}$ and evapotranspiration $1166 \mathrm{~mm}$ (SIAM-IMIDA, 2017).

The vegetation in the study area is steppe grassland (Fig. 2), dominated by the esparto grass (Stipa tenacissima). There was a partial reforestation with Pinus halepensis in the 1960s and 1970 s, although the trees developed poorly, probably due to rooting difficulties associated with the petrocalcic horizon. In July 1994, the study area suffered a catastrophic wildfire. Our study site is located close $(1-2 \mathrm{~km})$ to the eastern limit of the fire. At the end of 1996, the area was patchily reforested again using $P$. halepensis. The planting of pines was preceded by mechanical preparation of the soil by subsoiling to $1-1.5 \mathrm{~m}$ along the plantation rows, causing a significant disturbance both to the soil surface and profile. One-year old tree seedlings were planted in rows and spaced 2.5-3 m apart. The 19-ha plot studied was an experimental plot, which was subjected to a large number of different mechanical subsoiling techniques, which differed mainly in the way organic matter was added to each line of trees (for details see Barberá et al., 2005). Pine growth was slow and mortality high. After 16 years, the trees were rarely more than $3 \mathrm{~m}$ high and their cover sparse (Fig. 3). Mechanical preparation of the terrain combined with the presence of a shallow petrocalcic horizon resulted in large slabs of rock and stones being brought to the surface, creating a particular microtopography. Original soil surface

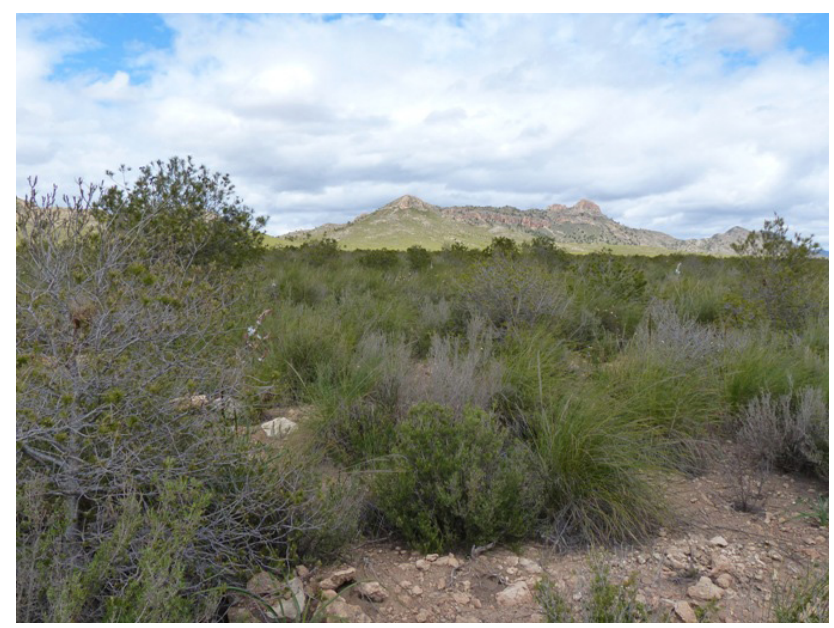

Fig. 3. Reforested area at the study site. 


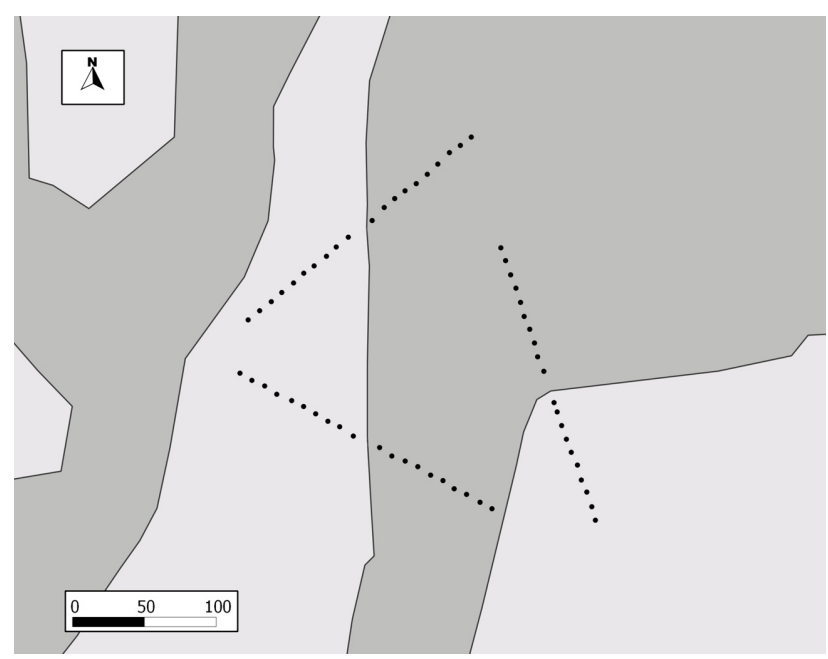

Fig. 4. Transects. Light gray - grassland; dark gray - reforested area.

was smooth with a varying density of small stones on the surface, while the subsoiled area is anfractuous at the microscale with a lot of large stones and rocks at the surface, which resulted from the breaking up of the hardpan during subsoiling.

\section{Sampling}

Three 200-m transects were established in May 2012 (Fig. 4). Each transect consisted of 20 pitfall traps set $10 \mathrm{~m}$ apart. Ten traps were placed in the reforested area, and 10 in the grassland. Because of the patchy structure of the reforested area, the distance of a pitfall from the edge of the grassland/reforested area may be less than the distance to the middle point of the transect (Fig. 4).

The ants were sampled using pitfall traps. Polystyrene tubes ( $2 \mathrm{~cm}$ diameter, $10.5 \mathrm{~cm}$ long) were installed two weeks before the traps were set in order to avoid the effects of digging-in (Greenslade, 1973), with the lip of the tube flush with the soil surface. Tubes were filled with $5 \mathrm{ml}$ of $50: 50$ propylene glycol and water solution with a few drops of liquid soap added to reduce surface tension (Bestelmeyer et al., 2000; Calixto et al., 2007) Pitfall traps were set for one week each season, in May, August, November 2012 and February 2013.

All ants were identified and counted using a stereo microscope. Identified ants were transferred to vials containing $70 \%$ ethanol, or were mounted. All specimens are deposited at the premises of Asociación de Naturalistas del Sureste (ANSE, Murcia, Spain).

To characterize the vegetation and soil surface one transect was established alongside each transect with the pitfall traps in March 2013. The purpose of these transects was to record the general characteristics of the composition of the vegetation and structure of the soil surface. Each transect was 8-m long, centred on each pitfall point and aligned with the original pitfall transect. At 17 points, at $50-\mathrm{cm}$ intervals, type of soil surface (cover of soil no stones or rocks on soil surface; superficial stones - hereafter stones; or in-ground rocks - hereafter rocks), species of plants and their height were recorded. Only perennial species were included in the analysis. Plants were categorized into functional groups (Table 1).

\section{Data analysis}

In order to determine the effects of reforestation on the ant assemblage and infer the possible causes we carried out two analyses. The first was for the whole year at the level of the assemblage. Numbers of each species caught in each pitfall on the four sampling sessions were summed and log-transformed. This matrix was submitted to non-metric multidimensional scal-
Table 1. Environmental variables and error function used for modelling response of the environmental and ant assemblage variables to reforestation in the framework of Generalized Linear Mixed Models (see Material and methods). Tree and perennial grass functional groups were not tested as each one is represented by only one species (Pinus halepensis and Stipa tenacissima, respectively). Note that error functions for total vegetation and functional groups were tested using a Poisson error as species in the same functional group can be overlaid on the same sampling point.

ENVIRONMENTAL VARIABLE $\quad$ Functional group $\begin{gathered}\text { Error } \\ \text { function }\end{gathered}$

\section{Soil surface}

Cover of soil (no stones or rocks

on soil surface)

Cover of stones

Cover of rocks

\section{Vegetation}

Plant species richness

Number of plant strata (NPS)

NPS on points with vegetation cover

Total cover of vegetation

Shrub cover

Chamaephyte cover

Pinus halepensis cover

Stipa tenacissima cover

Rosmarinus officinalis cover

Anthyllis terniflora cover

Cistus clusii cover

Fumana ericoides cover

Fumana thymifolia cover

Helianthemum violaceum cover

Olea europaea cover

Sideritis bourgeana cover

Binomial

Binomial

Binomial

Poisson

Poisson

Poisson

Poisson

Poisson

Poisson

Tree Binomial

Perennial grass Binomial

Shrub Binomial

Shrub Binomial

Shrub Binomial

Chamaephyte Binomial

Chamaephyte Binomial

Chamaephyte Binomial

Shrub Binomial

Chamaephyte Binomial

ing (NMDS) followed by an Adonis test (McArdle \& Anderson, 2001) to check if the between-group (grassland vs. reforestation) and within-group similarities differed significantly. Adonis is a permutation test that partitions the sum of squares for distance matrices in a way analogous to MANOVA. The number of permutations was set to 999. Relation between NMDS axes and environmental variables was tested using Spearman's rank correlation. These analyses were carried out using the vegan package (Oksanen et al., 2018) in R (R Core Team, 2018). The second analysis aimed to test the effects on the abundance of individual species as well as the abundance of the assemblage (all species summed) and species richness. It was hierarchically carried out in two steps: (i) testing if reforestation using MSP is associated with changes in soil and vegetation variables as well as in ant species richness and ant total abundance for each species; (ii) testing if ant species richness, total abundance and species specific variation were associated with the variation in the environmental variables that were significantly different in the two habitats, as tested in (i).

We hypothesized that these changes may be expressed in terms of three possible models (Fig. S1): (i) a shift in the levels of the different variables of interest in each habitat (factor); (ii) a linear trend (positive or negative) in the variable from inner part of the reforested area to that of the grassland; (iii) a unimodal trend with a maximum or a minimum value of the variable of interest close to the ecotone. In relation to environmental variables, to test for the most complex case (unimodal response) a generalized linear mixed model was fitted to each variable with transect as a random factor and signed distance to the ecotone set to zero and distance to inner part of the grassland assigned a positive sign and that to the inner part of reforested area a negative sign and its squared value as fixed factors. If the effect of the quadratic signed distance 


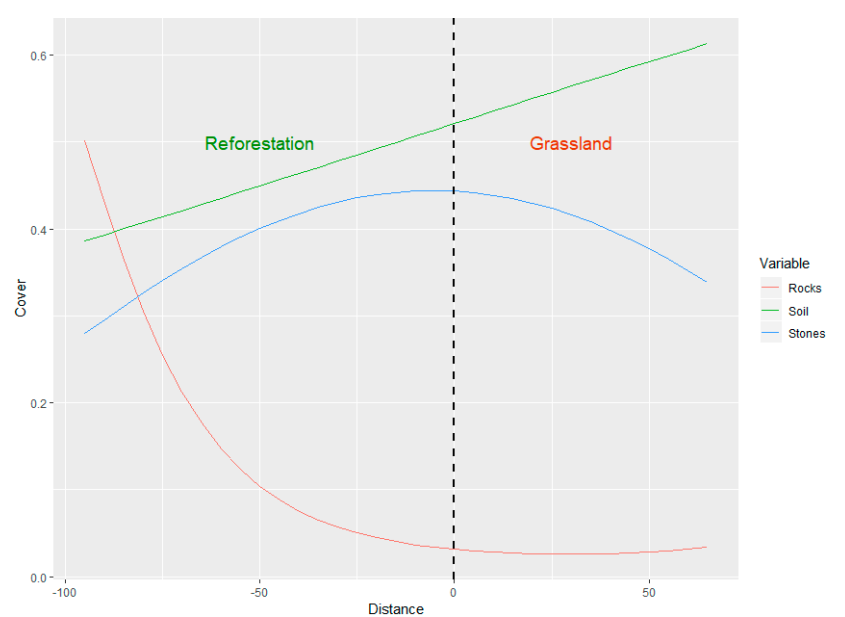

Fig. 5. Soil surface cover. Values predicted by the models (Table S1).

was statistically significant (indicating a unimodal response) the model was retained, otherwise we tested the alternative (less complicated) linear trend model with the signed distance without the quadratic term. Again, if the signed distance parameter was significant the model was retained, otherwise we tested for the shift model, which includes the habitat as a qualitative factor. For each response variable, the generalized linear mixed model was fitted with an error function appropriate for the nature of data (binomial, Poisson, normal; details in Table 1). Models for ant species richness and total abundance were tested similarly but because ants were sampled seasonally the fixed part of the generalized linear mixed model includes habitat and season. Ant species richness was tested at two spatial scales: pitfall and habitat $\times$ transect (10 aggregated traps in a particular habitat along a particular transect). For the species' abundance models, as autumn and winter abundances per individual species were very low, a full model, including habitat and season, is usually over parametrized. Therefore, for each species, we tested a model that included the year-round aggregated abundance and four seasonal models. Abundance data were log-transformed prior to analyses.

Generalized linear mixed models were fitted using the GLIMMIX procedure in SAS 9.4. Details of the statistically significant models are presented in Table S1. In the main text only graphical expressions of the models are shown.

Next, we determined whether the abundance and richness of ant species was correlated with environmental variables that significantly varied between habitats, using Spearman's rank correlation with the Benjamini-Hochberg correction for multiple comparisons (Benjamini \& Hochberg, 1995). This correction is less conservative than the Bonferroni one and is based on controlling the false discovery rate (FDR). We set FDR in this study to 0.2 , that is, we accept a maximum rate of false tests of $20 \%$.

\section{RESULTS}

\section{Environmental changes induced by reforestation}

Soil surface characteristics clearly vary between habitats (Figs 5-6; expected values of models are shown in Table S1). The cover of rocks was low and constant in the grassland and increased sharply towards the inner part of the reforested area. The cover of soil increased linearly from the centre of the reforested area to that of the grassland, while stone cover peaked close to the ecotone.
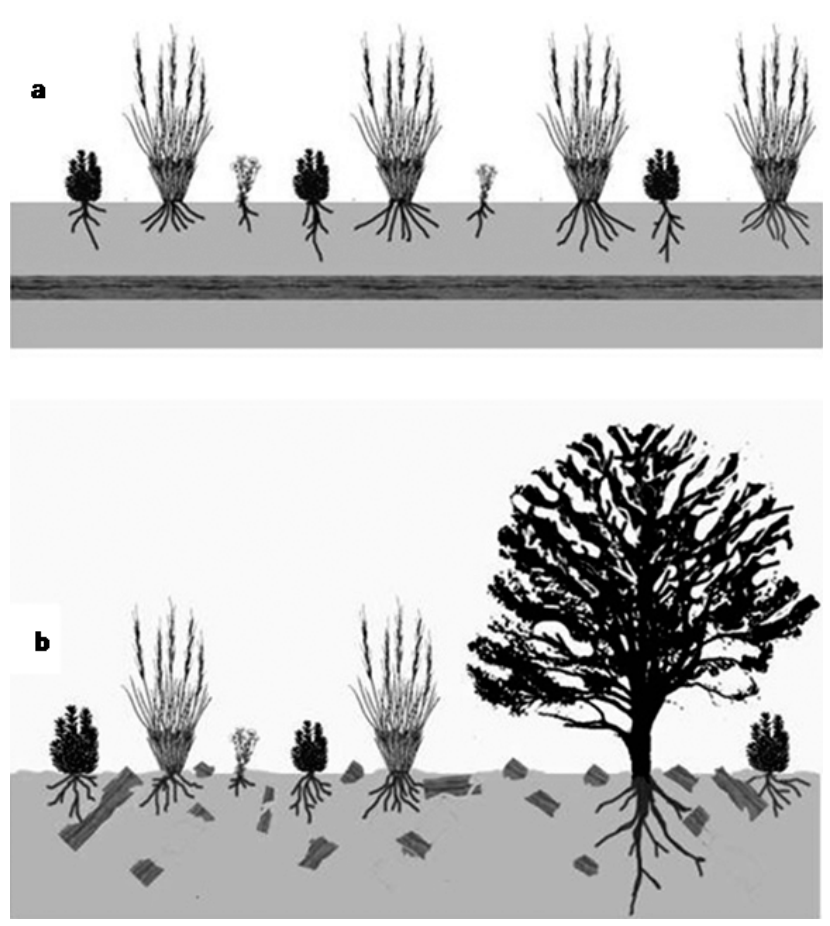

Fig. 6. Soil profile in the grassland (a) and reforested area (b). Note that the petrocalcic horizon $(\mathrm{Ckm})$ was lifted and fragmented by mechanical reforestation.

Changes in vegetation were not associated with differences in species richness or general physiognomy, but were with total vegetation, functional groups and, most importantly, species cover (Fig. 7; predicted values of the models are presented in Table S1). Of course, pine cover was only recorded in the reforested area. The two subdominant shrubs showed opposite linear trends. In the inner part of the grassland the cover of Cistus clusii and Rosmarinus officinalis was similar, whereas that of $C$. clusii decreased towards the inner part of the reforested area while that of R. officinalis increased. As a result, the total shrub cover remains unchanged. Stipa tenacissima was clearly dominant

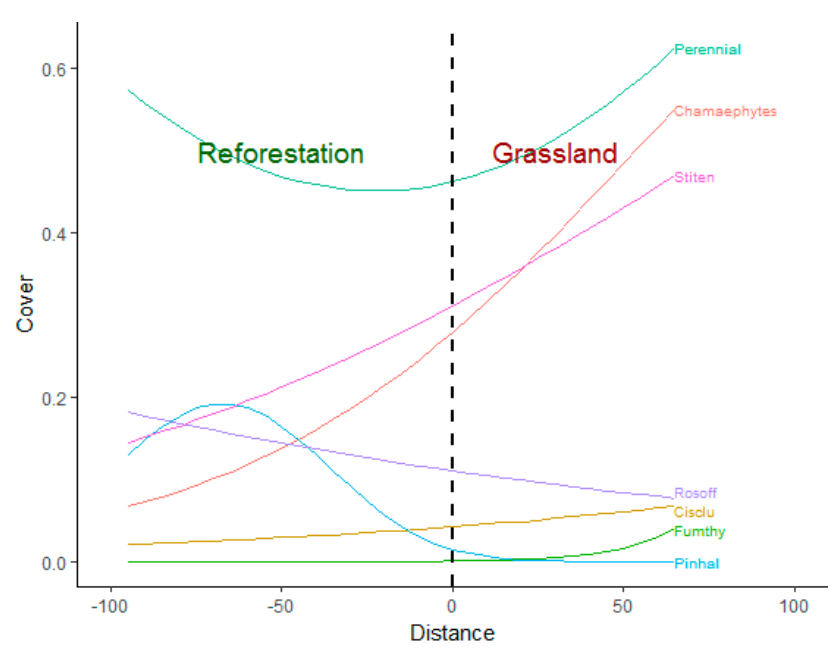

Fig. 7. Components of the cover of vegetation. Values predicted by the models (Table S1). Cisclu - Cistus clusii; Fumthy - Fumana thymifolia; Pinhal - Pinus halepensis; Rosof - Rosmarinus officinalis; Stiten - Stipa tenacissima. 


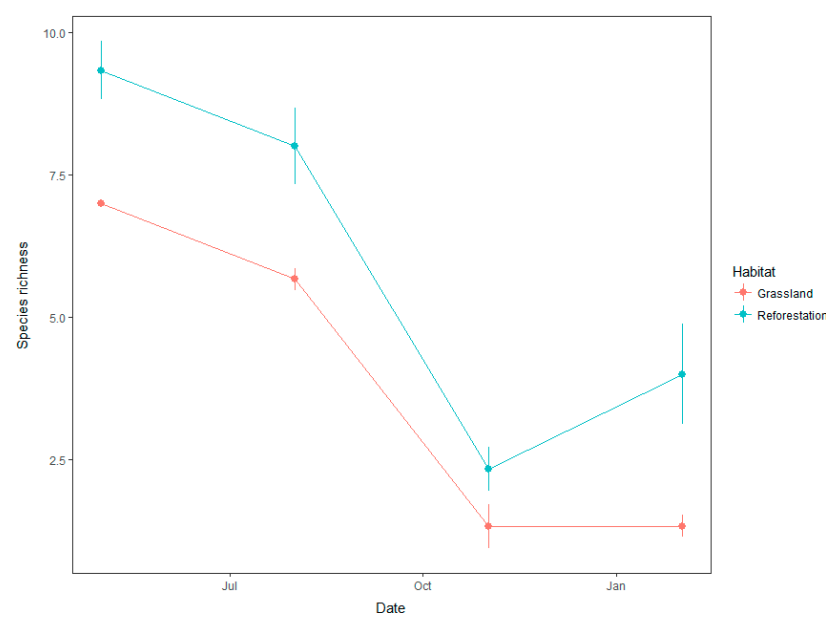

Fig. 8. Ant species mean richness along the transect. Bars indicate standard error as calculated from model in Table S1.

in grassland but far less abundant in the reforested site, to the point that in the inner part its cover was similar to that of $R$. officinalis. Total chamaephyte cover had a similar trend, but only one species of chamaephyte differed significantly between habitats: Fumana thymifolia. The cover of this tiny species was very low except in the inner part of the grassland. Interestingly, total perennial plant cover was similar in the inner parts of the forest and grassland but showed a minimum in the ecotone close to the reforested area.

\section{Effect of reforestation on ant assemblages}

A total of 13 species of ants belonging to 11 genera were recorded in this study (Table 2). Ten species were found in both habitats and three only in the reforested habitat. As Temnothorax racovitzai was only caught twice it was not included in the analysis.

Species richness at the habitat $\times$ transect scale was significantly higher in the reforested area (Fig. 8). The pattern did not differ between seasons. At the pitfall scale it is possible to detect a linear trend of decreasing richness from the inner part of the reforested area to that of the grassland (Fig. 9; predicted values of models are presented in Table

Table 2. Total number of each species of ant captured in the pitfall traps in grassland $(G)$ and the reforested area $(R)$.

\begin{tabular}{lcc}
\hline \multirow{2}{*}{ Ant species } & \multicolumn{2}{c}{ Captures } \\
\cline { 2 - 3 } & $\mathrm{G}$ & $\mathrm{R}$ \\
\hline Aphaenogaster iberica Emery, 1908 & 1 & 15 \\
Camponotus foreli Emery, 1881 & 4 & 18 \\
Camponotus sylvaticus (Olivier, 1792) & 0 & 12 \\
Cataglyphis iberica (Emery, 1906) & 75 & 111 \\
Crematogaster auberti Emery, 1869 & 55 & 18 \\
Goniomma blanci (André, 1881) & 23 & 2 \\
Messor bouvieri Bondroit, 1918 & 37 & 94 \\
Pheidole pallidula (Nylander, 1849) & 15 & 48 \\
Plagiolepis schmitzii Forel, 1895 & 52 & 53 \\
Tapinoma nigerrimum (Nylander, 1856) & 178 & 234 \\
Temnothorax racovitzai Bondroit, 1918 & 0 & 2 \\
Temnothorax specularis Emery, 1916 & 5 & 5 \\
Tetramorium semilaeve André, 1883 & 0 & 6 \\
\hline TOTAL & 445 & 618 \\
\hline
\end{tabular}

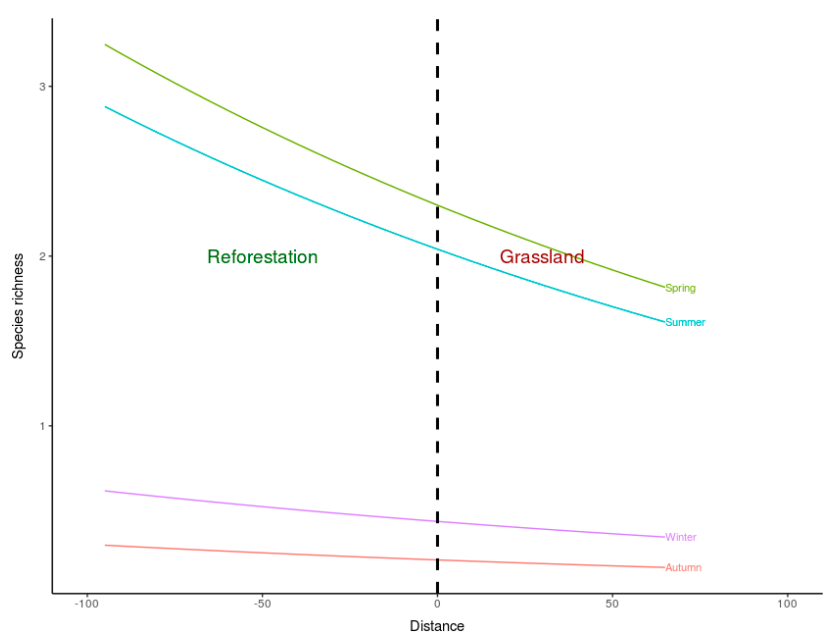

Fig. 9. Ant species mean richness per pitfall trap. Values predicted by the models (Table S1).

S1). Total ant abundance follows a very similar pattern (Fig. S2; predicted values of models are presented in Table $\mathrm{S} 1)$.

Reforestation had significant effects on the year-round abundance of several species and in spring and summer, when ants are much more active (Figs 10 and S3; predicted values of models are presented in Table S1). Plagiolepis schmitzii and Gonioma blanci were the only species that linearly increased in abundance from the inner part of the reforested area to that of the grassland. Plagiolepis schmitzii shows this trend year-round and in summer, whilst $G$. blanci shows this trend only in spring. More species decrease in abundance from the inner part of the reforested area to that of the grassland: Aphaenogaster iberica yearround and in both spring and summer, Camponotus sylvaticus year-round and in summer. For Camponotus foreli the trend also linearly decreased from the reforested area to the grassland year-round and in spring but in summer the response was unimodal with a maximum in the ecotone.

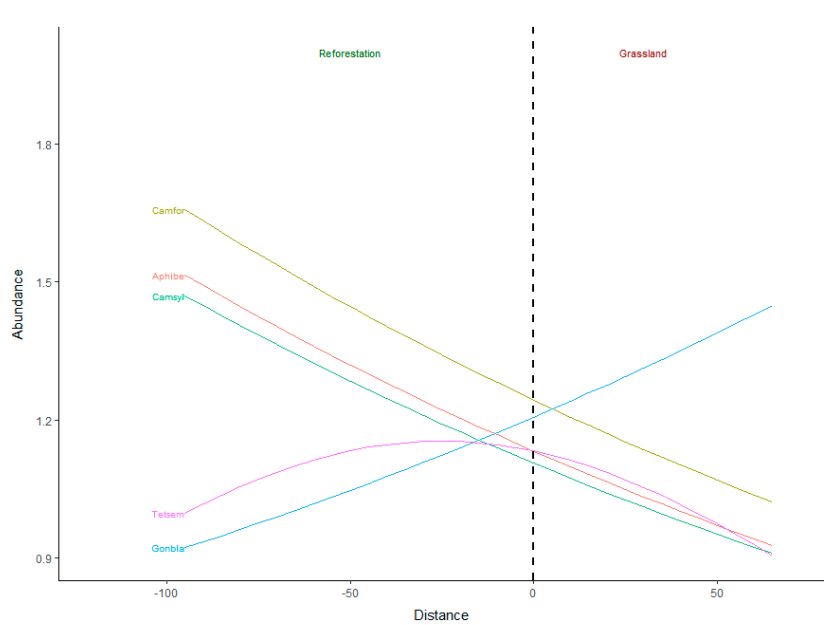

Fig. 10. Year-round abundance of the different species of ants. Values predicted by the models (Table S1). Aphibe - Aphaenogaster iberica; Camfor - Camponotus foreli; Camsyl - Camponotus sylvaticus; Gonbla - Goniomma blanci; Tetsem - Tetramorium semilaeve. 


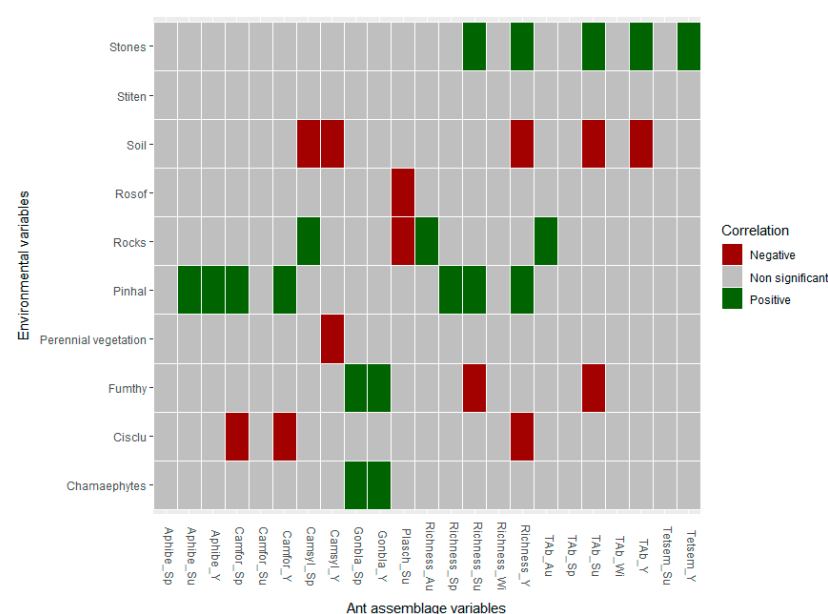

Fig. 11. Significant correlations and their direction (positive / negative) between the environmental variables and those of the ant assemblage. Original Spearman's correlation coefficients and $P$ values are in Table S2. Cisclu - Cistus clusii; Fumthy - Fumana thymifolia; Pinhal - Pinus halepensis; Rosof - Rosmarinus officinalis; Stiten - Stipa tenacissima; Tab - Total abundance; Aphibe - Aphaenogaster iberica; Camfor - Camponotus foreli; Camsyl - Camponotus sylvaticus; Gonbla - Goniomma blanci; Plasch Plagiolepis schmitzii; Tetsem - Tetramorium semilaeve. Y - yearround; Sp - spring; Su - summer; $\mathrm{Au}$ - Autumn; $\mathrm{Wi}$ - winter.

This kind of unimodal response is also characteristic of $T e$ tramorium semilaeve year-round and in summer.

\section{Correlation between the differences in the environmental factors in the two habitats and in the ant assemblages}

There were significant correlations between environmental variables and the ant assemblage variables that differed significantly in the two habitats (Fig. 11, Table S2), as stated in the previous section. Ant species richness yearround and when most active in spring and summer was positively associated with the cover of $P$. halepensis, also species richness year-round and in summer was associated positively with the cover of stones. In autumn ant species richness was positively associated with the cover of rocks. Year-round ant species richness was negatively associated with $C$. clusii and a continuous cover of soil.

Total ant abundance year-round was positively associated with the cover of stones, as was total ant abundance in summer. As for ant species richness, seasonal total ant abundance in autumn was positively associated with the cover of rocks. In contrast, total ant abundance was negatively correlated year-round with a continuous cover of soil and in summer with the cover of $F$. thymifolia.

In respect to specific species, $G$. blanci year-round and spring abundances were positively associated with the cover of chamaephytes and with that of $F$. thymifolia. Aphaenogaster iberica year-round and summer abundances were positively associated with the cover of $P$. halepensis, like the abundance year-round and in spring of $C$. foreli. Also for $C$. foreli and the same seasons there was a negative association with the cover of C. clusii. Camponotus sylvaticus, however was positively associated with the cover of rocks in spring and negatively with a continuous cover of soil.

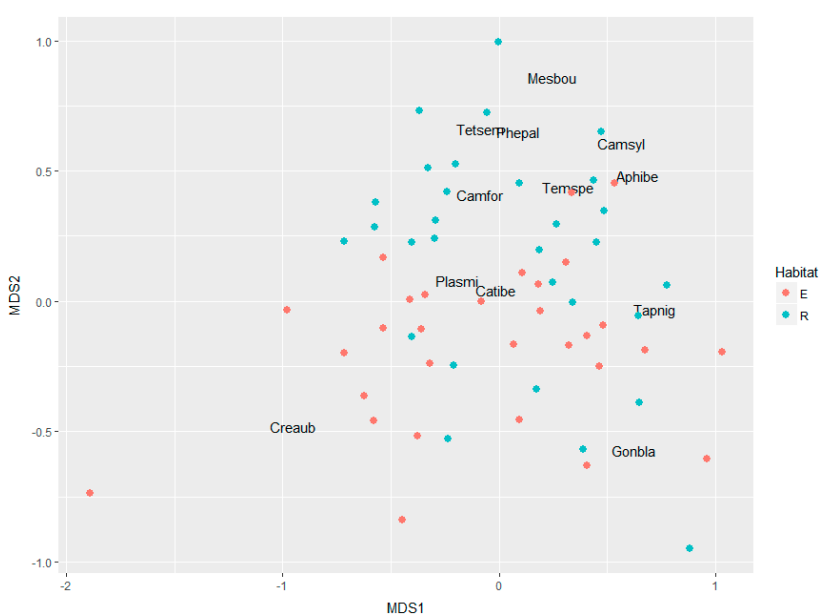

Fig. 12. NMDS Representation of the NMDS analysis. Aphibe Aphaenogaster iberica; Camfor - Camponotus foreli; Camsyl -Camponotus sylvaticus; Catibe - Cataglyphis iberica; Creaub - Crematogaster auberti; Gonbla - Goniomma blanci; Mesbou Messor bouvieri; Phepal - Pheidole pallidula; Plasch - Plagiolepis schmitzii; Tapnig - Tapinoma nigerrimum; Temspe - Temnothorax specularis; Tetsem - Tetramorium semilaeve.

NMDS axis 1 clearly separated Crematogaster auberti from the rest of the species, but not the pitfall trap catches by habitat (Fig. 12). In contrast, axis 2 segregated the reforested area from grassland, although there was a considerable overlap between groups. Nevertheless, the Adonis test shows significant differences between pitfall trap catches in the reforested area and grassland (pseudo-F $=3.18, \mathrm{p}=$ 0.013 ) but the partial $\mathrm{R}^{2}$ of the habitat factor was low (5\%). NMDS axis 1 was only significantly correlated with perennial plant richness (Table 3; positive correlation), while NMDS axis 2 was positively correlated with the cover of stones and Pinus halepensis and negatively with Sideritis bourgeana, chamaephytes and a continuous cover of soil.

\section{DISCUSSION}

\section{Environmental changes induced by reforestation}

Vegetation and soil were disturbed by reforestation. We did not find a shift but mostly linear trends of different signs depending on the variable. Without doubt, this is related to the detailed spatial scale of the study, itself conditioned by the patchy design of the reforested area.

The disruption caused by mechanical soil preparation removed a large proportion of the dominant species of the grassland (Stipa tenacissima), which resulted in a reduction in its cover of $>60 \%$ in the inner part of the refor-

Table 3. NMDS Correlations between environmental variables and coordinates of samples (pitfall trap catches) in the NMDS space.

\begin{tabular}{|c|c|c|c|c|}
\hline \multirow[b]{2}{*}{ Variable } & \multicolumn{2}{|c|}{ NMDS Axis 1} & \multicolumn{2}{|c|}{ NMDS Axis 2} \\
\hline & $\begin{array}{l}\text { Spearman's } \\
\text { correlation }\end{array}$ & $p$ & $\begin{array}{l}\text { Spearman's } \\
\text { correlation }\end{array}$ & $p$ \\
\hline Perennial plant richness & 0.336 & 0.009 & & \\
\hline Chamaephyte cover & & & -0.308 & 0.010 \\
\hline Sideritis bourgeana cover & & & -0.290 & 0.025 \\
\hline Pinus halepensis cover & & & 0.447 & $<0.001$ \\
\hline Stone cover & & & 0.462 & $<0.001$ \\
\hline $\begin{array}{l}\text { Cover of soil (no stones } \\
\text { or rocks on soil surface) }\end{array}$ & & & -0.484 & $<0.001$ \\
\hline
\end{tabular}


ested area compared to that in the inner part of the grassland area (Fig. 7). In our study area, the rate of emergence of seedlings of $S$. tenacissima is very low due to the high predation of seeds (by ants) and no germination on bare soil, with only germination occurring within tussocks of $S$. tenacissima (Barberá et al., 2006). Thus, the recolonization of reforested area by this species is very slow. The introduced Pinus halepensis developed poorly (Barberá et al., $2005)$ but in the inner part of reforested area its cover was similar to that of $S$. tenacissima. The abundance of the two subdominant shrubs differed in the two habitats. That of Cistus clusii and other Cistaceae was lower in the reforested habitat probably because their seed banks only become highly active after fires (Thanos et al., 1992). In contrast, Rosmarinus officinalis increased in the open spaces left by the removal of $S$. tenacissima during reforestation, as this species has an active seed bank and good colonization potential. In summary, reforestation greatly changed the structure of the grassland, reducing especially the cover of S. tenacissima and Cistaceae, which were the main taxa in the original grassland. On a more detailed scale the changes are gradual, not abrupt. Neither plant species richness nor the general physiognomy of the vegetation (vertical structure and overlaying) was significantly affected, as the poor growth of $P$. halepensis resulted in a shrub-like structure not very different from that of the original grassland.

Soil surface was changed greatly by reforestation. The mechanical preparation of the site broke through the petrocalcic hardpan and brought large numbers of rocks to the surface of the soil. Within our study area, the surface of soil in the grassland characteristically consisted mainly of a continuous cover of soil with a few rocks on the surface and moderate abundance of stones. Cover of stones was highest in the ecotone. This can be probably explained by the disturbance caused by vehicles turning and manoeuvring between reforestation rows (pers. obs.). Consistent with this hypothesis is the lower cover of perennial plants in the ecotone.

\section{Effect of reforestation on ant assemblages}

There was higher ant species richness (increase $>70 \%$ at the scale of transect $\times$ habitat accounting for the whole year and $>50 \%$ of pitfall catches at a distance of $60 \mathrm{~m}$ from the ecotone in the spring-summer season) and of total abundance by $>100 \%$ in the reforested area. Nevertheless, the multivariate analysis (Fig. 12) indicates that the first trend in variation (axis 1) is unrelated to reforestation and is characterized by $C$. auberti differing from the other species in occurring in areas with a poor plant species richness. The second trend in variation indicates that the pitfall catches differ in the two habitats and, although there is overlap this may be a result of a gradual change in the environment between two habitats. The Adonis test was, however, significant. In summary, reforestation clearly changed the ant assemblage.

Previous studies on the transition from grassland to forest found a variety of effects: highest species richness at the ecotone (Downie et al.,1996; Pinheiro et al., 2010), increasing linear response in species richness from forest to grassland (Kotze \& Samways, 2001; Yekwayo et al., 2016), or an increasing linear response in species richness from grassland to forest (Bieringer \& Zulka, 2003), as in this study. It seems that the response of arthropods to changes in their habitat resulting from reforestation may be case- and taxon-specific.

Although patterns at the level of the ant assemblage were clear (specially for species richness and total abundance), on a species by species basis they are fuzzier. There are two possible reasons for this. The most abundant species (Tapinoma nigerrimum) may be a generalist not affected by changes induced by reforestation, and the others are scarce species for which random noise may obscure any effects. Nevertheless, two species were significantly more abundant in the grassland, four more abundant in the reforested area, and two in the ecotone. More species responded positively than negatively to reforestation. The underlying causes of this are mainly related to the changes in the vegetation and soil. Corley et al.'s (2006) study of the effects of pine afforestation on arid grasslands dominated by Stipa spp. on the Patagonian steppe reveals that open forest plantations have ant assemblages similar to those on native steppes. Other authors report that scattered presence of trees or invasion by shrubs of open grassland is associated with an increase in species richness and abundance of ants (Bestelmayer, 2005; Azcárate \& Peco, 2012). This may be due to several factors. Reyes-López et al. (2003) report that some species are more common near trees than in open areas, suggesting that milder thermal environments may favour ants. However, a high density of trees on open grassland has an adverse effect on the ant assemblage (Reyes-López et al., 2003; Corley et al., 2006).

The results of this study are consistent with an improvement in the conditions for ants in grasslands with scattered shrubs and/or trees, as in our case. Year-round ant species richness and the abundances of two species of ants (Camponotus foreli and Aphaenogaster iberica) were positively correlated with the cover of $P$. halepensis, and the cover of this species is also correlated with axis 2 , which segregates pitfall trap results by habitat. Trees are exclusive to the reforested area, but being widely spread and small they do not constitute a forest, but shrub land, with no more vegetation cover than the grassland. But, typically, for the same cover the biomass is much greater than that of shrubs and probably the microhabitats associated with trees are quite different from those associated with $S$. tenacissima and dominant shrubs. Not all the effects of the changes in vegetation were positive. Goniomma blanci was more abundant in grassland than in the reforested area. Furthermore, the abundance of this species was positively associated with Fumana thymifolia (a Cistaceae species) in spite of the low cover of this plant. Goniomma kugleri, another species of this genus on the Iberian Peninsula is specialized in harvesting the seeds of Cistaceae (Bastida et al., 2009), therefore it is very probable that $G$. blanci is similarly specialized and this would explain its lower abundance in the reforested area where the cover of Cistaceae is considerably less than in the grassland. 
Food and nesting space are the most important resources for ants (Blüthgen \& Feldhaar, 2010). A higher cover of stones and rocks provide more cool shelters for ant nests (Fernández-Escudero et al., 1993; Thomas, 2002; Robinson, 2008). Indeed, thermal properties of rocks benefit ants in two ways: by reducing high temperatures during hot weather, and by rapid and effective absorption of solar heat in cold weather, enabling better brood development (Dean \& Turner, 1991; Thomas, 2002). Furthermore, rocks protect colonies against predators, and in addition the soil below these stones is moister and therefore easier to excavate (Dean \& Turner, 1991). Reyes-López et al. (2003) report that in an open forest in Sierra Morena (Spain), the relationship between availability of stones for nesting and number of ant nests is positive. Dahms et al. (2010), studying semi-natural grasslands in Sweden, report a positive relationship between rock cover and ant species richness. Finally, Friedrich \& Philpott (2009) suggest that intraspecific and interspecific competition may be less when there is an abundance of nest sites.

In the reforestation, the planting of pines was preceded by mechanical preparation of the site, which resulted in a major disturbance of the surface properties of the soil. The petrocalcic horizon in the soil was partially broken, fragmented and mixed with the surface horizon. This increased the frequency of stones and rocks and reduced the cover of soil. Total ant species richness and total ant abundance was positively correlated with the number of stones on the surface of the soil and the segregation by the NMDS analysis (axis 2) of pitfall trap catches by habitat was correlated with the cover of stones and soil. The abundance of Camponotus sylvaticus, which is known to shelter under stones/ rocks, is negatively correlated with the cover of soil. More interestingly, the positive association of ant species richness and abundance with rock cover occurs in autumn but not year-round or in spring-summer, indicating a positive heating effect in cooler seasons.

The reforested area in this study is a more heterogeneous habitat, especially when jointly considering soil and vegetation and not just vegetation. Small-scale habitat complexity influences interspecific competition and resource use in ant communities, which results in differences among species that contribute to resource partitioning and permit subordinate species to avoid competition resulting in a greater diversity of ants (Luque \& Reyes, 2007). Tews et al. (2004) introduce the concept of "keystone structures" in terms of vegetation complexity as a distinct spatial structure, which provides resources, shelter or "goods and services" crucial for other species. It would seem that both the abundance of stones on the surface of the soil and the small size of the pines in the system studied may match the concept of a keystone structure for ant assemblages.

\section{CONCLUSIONS}

The changes in the vegetation summarised by the decrease in the cover of $S$. tenacissima and Cistaceae, basic elements in grassland, and an increase in the cover of pine seems to provide more resources for the ant assemblage.
The parallel disturbance of the soil seems to increase the availability of shelters. Altogether, these changes resulted in an increase in the richness and abundance of ants. Nevertheless, the positive effect of disturbing soil during reforestation is probably not the norm. Most mechanized reforestation in the Mediterranean was carried out on hillslopes and resulted in extensive erosion and large bare patches that are extremely slowly recolonized by vegetation (especially on escarpments under terraces), very different from the gentle slopes studied here.

ACKNOWLEDGEMENTS. Many thanks to X. Espadaler for his invaluable help, R. Gómez for reviewing the manuscript, B. Seifert for identifying Tapinoma nigerrimum, and M. Guillén and K. Peel for correcting the English version. Finally, we thank the two anonymous reviewers and the editors for their helpful suggestions. The authors declare there are no conflicts of interest.

\section{REFERENCES}

AzcÁrate F.M. \& Peco B. 2012: Abandonment of grazing in a mediterranean grassland area: Consequences for ant assemblages. — Insect Conserv. Divers. 5: 279-288.

Barberá G.G., Martínez-Fernández F., Álvarez-Rogel J., AlBALADEJO J. \& CASTILlO V. 2005: Short- and intermediate-term effects of site and plant preparation techniques on reforestation of a Mediterranean semiarid ecosystem with Pinus halepensis Mill. - New Forests 29: 77-198.

Barberá G.G., Navarro-Cano J.A. \& Castillo V.M. 2006: Seedling recruitment in a semiarid steppe: The role of microsite and post-dispersal seed predation. — J. Arid Environ. 67: 701-714.

Bastida F., Talavera S., Ortiz P.L. \& Arista M. 2009: The interaction between Cistaceae and a highly specific seed-harvester ant in a Mediterranean scrubland. - Plant Biol. 11: 46-56.

Belloce M.I., Smith S.M. \& Doka M.E. 2001: Short-term effects of harvest technique and mechanical site preparation on arthropod communities in jack pine plantations. - J. Insect Conserv. 5: 187-196.

Benjamini Y. \& Hochberg Y. 1995: Controlling the false discovery rate: A practical and powerful approach to multiple testing. - J. R. Stat. Soc. (B) 57: 289-300.

Bestelmeyer B.T. 2005: Does desertification diminish biodiversity? Enhancement of ant diversity by shrub invasion in southwestern USA. - Divers. Distrib. 11: 45-55.

Bestelmeyer B.T. \& Wiens J.A. 2001: Ant biodiversity in semiarid landscape mosaics: The consequences of grazing versus natural heterogeneity. - Ecol. Appl. 11: 1123-1140.

Bestelmeyer B.T., Agosti D., Alonso L.E., Brandão C.R.F., Brown W.L., Delabie J.H.C. \& Silvestre R. 2000: Field techniques for the study of ground-dwelling ants. In Agosti D., Mayer D., Alonso L.E. \& Schultz R. (eds): Ants: Standard Methods for Measuring and Monitoring Biodiversity. Smithsonian Institution Press, Washington, D.C., pp. 122-144.

Bieringer G. \& ZulKa K.P. 2003: Shading out species richness: edge effect of a pine plantation on the Orthoptera (Tettigoniidae and Acrididae) assemblage of an adjacent dry grassland. - Biodivers. Conserv. 12: 1481-1495.

Bird S.B., Coulson R.N. \& Fisher R.F. 2004: Changes in soil and litter arthropod abundance following tree harvesting and site preparation in a loblolly pine (Pinus taeda L.) plantation. Forest Ecol. Manag. 202: 195-208.

Blüthgen N. \& FeldhaAR H. 2010: Food and shelter: how resources influence ant ecology. In Lach L., Parr C. \& Abbot K. (eds): Ant Ecology. Oxford University Press, New York, pp. 115-136. 
Calixto A.A., Harris M.K. \& Dean A. 2007: Sampling ants with pitfall traps using either propyleneglycol or water as a preservative. - Southwest. Entomol. 32: 87-91.

Chaparro J. \& Esteve-Selma M.A. 1995: Evolución geomorfológica en laderas repobladas mediante aterrazamientos en ambientes semiáridos (Murcia, SE de España). - Cuatern. Geomorfol. 9: 39-49.

Corley J., Sackmann P., Rusch V., Bettinelli J. \& Paritsis J. 2006: Effects of pine silviculture on the ant assemblages (Hymenoptera: Formicidae) of the Patagonian steppe. - Forest Ecol. Manag. 222: 162-166.

Cortina J., Maestre F.T. \& Ramírez D. 2009: Innovations in semiarid land restoration. The case of Stipa tenacissima L. steppes. In Bautista S., Aronson R.J. \& Vallejo R. (eds): Land Restoration to Combat Desertification. Innovative Approaches, Quality Control and Project Evaluation. Fundación CEAM, Valencia, pp. 121-144.

Costa M. 1973: Datos ecológicos y fitosociológicos sobre los espartales de la provincia de Madrid. - An. Inst. Bot. A.J. Cavanillo 30: 233-255.

Dahms H., Lenoir L., Lindborg R., Wolters V. \& Dauber J. 2010: Restoration of seminatural grasslands: what is the impact on ants? - Restor. Ecol. 18: 330-337.

DeAn W.R.J. \& TuRNER J.S. 1991: Ants nesting under stones in the semi-arid Karoo, South Africa: predator avoidance or temperature benefits? - J. Arid Environ. 21: 59-69.

Del Toro I., Ribbons R.R. \& Pelini S.L. 2012: The little things that run the world revisited: a review of ant-mediated ecosystem services and disservices (Hymenoptera: Formicidae). Myrmecol. News 17: 133-146.

Doblas-Miranda E., Sánchez-Piñero F. \& GonzÁlez-Megías A. 2007: Soil macroinvertebrate fauna of a Mediterranean arid system: Composition and temporal changes in the assemblage. - Soil Biol. Biochem. 39: 1916-1925.

Downie I.S., Coulson J.C. \& ButTerfield J.E. 1996: Distribution and dynamics of surface-dwelling spiders across a pastureplantation ecotone. - Ecography 19: 29-40.

FAO-ISRIC-ISSS 1998: World Reference Base for Soil Resources. World soil resources reports, 84. Food and Agricultural Organisation of the United Nations (FAO), International Soil Reference and Information Centre (ISRIC) \& International Society of Soil Science (ISSS), Rome, $85 \mathrm{pp}$.

Férnandez-Escudero I., Tinaut A. \& Ruano F. 1993: Rock selection for nesting in Proformica longiseta Collingwood (Hymenoptera: Formicidae) in a Mediterranean high mountain. - Int. J. Biometeorol. 37: 83-88.

Folgarait P.J. 1998: Ant biodiversity and its relationship to ecosystem functioning: a review. - Biodivers. Conserv. 7: 12211244.

Friedrich R. \& PhiLPott S.M. 2009: Nest-site limitation and nesting resources of ants (Hymenoptera: Formicidae) in urban green spaces. - Environ. Entomol. 38: 600-607.

Frouz J. \& JiLkova V. 2008: The effect of ants on soil properties and processes (Hymenoptera: Formicidae). - Myrmecol. News 11: 191-199.

Greenslade P.J.M. 1973: Sampling ants with pitfall traps: Digging-in effects - Insectes Soc. 20: 343-353.

Haeussler S., Bedford L., Boateng J.O. \& MacKinnon A. 1999: Plant community responses to mechanical site preparation in northern interior British Columbia. - Can. J. Forest Res. 29: 1084-1100.

HöLdobler B. \& Wilson E.O. 1990: The Ants. Harvard Belknap, Cambridge, 732 pp.
Kotze D.J. \& SAmways M.J. 2001: No general edge effects for invertebrates at Afromontane forest/grassland ecotones. - Biodivers. Conserv. 10: 443-466.

LöF M., Dey D.C., Navarro R.M. \& Jacobs D.F. 2012: Mechanical site preparation for forest restoration. - New Forests 43: 825-848.

LuQue G.M. \& ReYes J. 2007: Effect of experimental smallscale spatial heterogeneity on resource use of a Mediterranean ground-ant assemblage. - Acta Oecol. 32: 42-49.

Maestre F.T., Ramirez D.A. \& Cortina J. 2007: Ecología del esparto (Stipa tenacissima L.) y los espartales de la Península Ibérica. - Ecosistemas 16: 111-130.

MCARDLE B.H. \& ANDERSON M.J. 2001: Fitting multivariate models to community data: A comment on distance-based redundancy analysis. - Ecology 82: 290-297.

Nash M.S., Whitford W.G., Van Zee J. \& Havstad K.M. 2000: Ant (Hymenoptera: Formicidae) responses to environmental stressors in the Northern Chihuahuan Desert. - Environ. Entomol. 29: 200-206.

Orsanen J., Guillaume Blanchet F., Friendly M., Kindt R., Legendre P., McGlinn D., Minchin P.R., O’Hara R.B., Simpson G., Solymos P., Stevens M.H.H., Szoecs E. \& Wagner H. 2018: vegan: Community Ecology Package. R package version 2.5-1. In R Core Team: R: A Language and Environment for Statistical Computing. R Foundation for Statistical Computing, Vienna. URL: https://CRAN.R-project.org/package=vegan

Ortigosa L.M. 1991: Las Repoblaciones Forestales en La Rioja: Resultados y Efectos Geomorfológicos. Monografias Cientificas 2. Geoforma Ediciones, Logroño, 149 pp.

Pinheiro E.R., Duarte L.D.S., Diehl E. \& Hartz S.M. 2010: Edge effects on epigeic ant assemblages in a grassland-forest mosaic in southern Brazil. - Acta Oecol. 36: 365-371.

Piñero F.S., Tinaut A., Aguirre-Segura A., Miñano J., Lencina J.L., Ortiz-SÁnchez F.J. \& Pérez-LÓPez F.J. 2011: Terrestrial arthropod fauna of arid areas of SE Spain: Diversity, biogeography, and conservation. - J. Arid Environ. 75: 1321-1332.

R CORE TEAm 2018: $R$ : A Language and Environment for Statistical Computing. R Foundation for Statistical Computing, Vienna. URL: https://www.R-project.org/.

READ J.L. \& ANDERSEN A.N. 2000: The value of ants as early warning bioindicators: responses to pulsed cattle grazing at an Australian arid zone locality. - J. Arid Environ. 45: 231-251.

Reyes-López J., Ruiz N. \& Fernández-Haeger J. 2003: Community structure of ground-ants: the role of single trees in a Mediterranean pastureland. - Acta Oecol. 24: 195-202.

RoBinson W.A. 2008: Selection and sharing of sheltered nest sites by ants (Hymenoptera: Formicidae) in grasslands of the Australian Capital Territory. - Aust. J. Entomol. 47: 174-183.

SIAM-IMIDA 2017: Sistema de Información Agraria de Murcia. Comunidad Autónoma de la Región de Murcia. URL: http:// siam.imida.es/ (last accessed 21 July 2017).

Ternan J.L., Williams A.G., Elmes A. \& Fitzjohn C. 1996: The effectiveness of bench-terracing and afforestation for erosion control on Raña sediments in central Spain. - Land Degrad. Dev. 7: 337-351.

Tews J., Brose U., Grimm V., Tielbörger K., Wichmann M.C., Schwager M. \& Jeltsch F. 2004: Animal species diversity driven by habitat heterogeneity/diversity: the importance of keystone structures. - J. Biogeogr. 31: 79-92.

Thanos C.A., Georghiou K., Kadi C. \& Pantazi C. 1992: Cistaceae: a plant family with hard seeds. - Israel J. Bot. 41: 251263.

Thomas M.L. 2002: Nest site selection and longevity in the ponerine ant Rhytidoponera metallica (Hymenoptera, Formicidae). - Insectes Soc. 49: 147-152. 
Valdés A. \& Herranz J.M. 1989: Matorrales de la Provincia de Albacete: Espartales, Romerales y Tomillares. Instituto de Estudios Albacetenses, Albacete, $72 \mathrm{pp}$.

WieziK M., Svitok M., WieziKová A. \& Dovčiak M. 2013: Shrub encroachment alters composition and diversity of ant communities in abandoned grasslands of western Carpathians. - Biodivers. Conserv. 22: 2305-2320.
Yekwayo I., Pryke J.S., Roets F. \& Samways M.J. 2016: Responses of ground living arthropods to landscape contrast and context in a forest-grassland mosaic. - Biodivers. Conserv. 26: $631-651$.

Received February 24, 2018; revised and accepted August 17, 2018 Published online October 12, 2018

Table S1. Full structure and basic statistics of the parameters of the generalized linear mixed models statistically significant according with the procedures described in the Methods. For each model the link function (transformation of the dependent variable) and the adequate error function is indicated. Figures in the main text are represented after inverting the link function, i.e., on the original scale of the dependent variable. Signed distance is the distance to the ecotone, with negative sign to the inner reforestation and positive sign for the inner grassland.

\begin{tabular}{|c|c|c|c|c|c|c|c|}
\hline \multirow{2}{*}{\multicolumn{8}{|c|}{ SOIL VARIABLES }} \\
\hline & & & & & & & \\
\hline \multicolumn{6}{|l|}{ Cover of soil } & Logit & Binomial \\
\hline Effect & Estimate & SE & $D F$ & $t$ Value & $\operatorname{Pr}>|t|$ & & \\
\hline Intercept & 0.08656 & 0.1396 & 2 & 0.62 & 0.5986 & & \\
\hline Signed distance to ecotone & 0.005765 & 0.002494 & 53 & 2.31 & 0.0247 & & \\
\hline \multicolumn{6}{|l|}{ Stones } & Logit & Binomial \\
\hline Effect & Estimate & $S E$ & $D F$ & $t$ Value & $\operatorname{Pr}>|t|$ & & \\
\hline Intercept & -0.2271 & 0.1666 & 2 & -1.36 & 0.306 & & \\
\hline Signed distance to ecotone & -0.00098 & 0.002907 & 52 & -0.34 & 0.7367 & & \\
\hline Signed distance to ecotone ${ }^{2}$ & -0.00009 & 0.000042 & 52 & -2.03 & 0.0472 & & \\
\hline \multicolumn{6}{|l|}{ Rocks } & Logit & Binomial \\
\hline Effect & Estimate & SE & $D F$ & $t$ Value & $\operatorname{Pr}>|t|$ & & \\
\hline Intercept & -3.4364 & 0.3914 & 2 & -8.78 & 0.0127 & & \\
\hline Signed distance to ecotone & -0.01381 & 0.006405 & 52 & -2.16 & 0.0358 & & \\
\hline Signed distance to ecotone ${ }^{2}$ & 0.000236 & 0.000087 & 52 & 2.72 & 0.0087 & & \\
\hline \multicolumn{8}{|l|}{ VEGETATION VARIABLES } \\
\hline \multicolumn{6}{|l|}{ Cistus clusii } & Logit & Binomial \\
\hline Effect & Estimate & $S E$ & $D F$ & $t$ Value & $\operatorname{Pr}>|t|$ & & \\
\hline Intercept & -3.1201 & 0.158 & 2 & -19.75 & 0.0026 & & \\
\hline Signed distance to ecotone & 0.00757 & 0.003849 & 53 & 1.97 & 0.0545 & & \\
\hline \multicolumn{6}{|l|}{ Fumana thymifolia } & Logit & Binomial \\
\hline Effect & Estimate & SE & $D F$ & $t$ Value & $\operatorname{Pr}>|t|$ & & \\
\hline Intercept & -7.1428 & 1.5162 & 2 & -4.71 & 0.0422 & & \\
\hline \multirow{2}{*}{\multicolumn{6}{|c|}{ Pinus halepensis }} & & \\
\hline & & & & & & Logit & Binomial \\
\hline Effect & Estimate & $S E$ & $D F$ & $t$ Value & $\operatorname{Pr}>|t|$ & & \\
\hline Intercept & -4.2097 & 0.5019 & 2 & -8.39 & 0.0139 & & \\
\hline Signed distance to ecotone & -0.08226 & 0.01956 & 52 & -4.21 & 0.0001 & & \\
\hline Signed distance to ecotone ${ }^{2}$ & -0.00061 & 0.000192 & 52 & -3.17 & 0.0026 & & \\
\hline \multicolumn{6}{|l|}{ Rosmarinus officinalis } & Logit & Binomial \\
\hline Effect & Estimate & SE & $D F$ & $t$ Value & $\operatorname{Pr}>|t|$ & & \\
\hline Intercept & -2.0836 & 0.1214 & 2 & -17.16 & 0.0034 & & \\
\hline Signed distance to ecotone & -0.0061 & 0.002584 & 53 & -2.36 & 0.022 & & \\
\hline \multicolumn{6}{|l|}{ Stipa tenacissima } & Logit & Binomial \\
\hline Effect & Estimate & SE & $D F$ & $t$ Value & $\operatorname{Pr}>|t|$ & & \\
\hline Intercept & -0.7936 & 0.2336 & 2 & -3.4 & 0.0768 & & \\
\hline Signed distance to ecotone & 0.01034 & 0.00227 & 53 & 4.56 & $<0.0001$ & & \\
\hline \multicolumn{6}{|l|}{ Chamaephytes cover } & $\log$ & Poisson \\
\hline Effect & Estimate & SE & $D F$ & $t$ Value & $\operatorname{Pr}>|t|$ & & \\
\hline Intercept & -0.9466 & 0.366 & 2 & -2.59 & 0.1226 & & \\
\hline Signed distance to ecotone & 0.01771 & 0.005334 & 53 & 3.32 & 0.0016 & & \\
\hline \multicolumn{6}{|l|}{ Total vegetation cover } & Logit & Binomial \\
\hline Effect & Estimate & SE & $D F$ & $t$ Value & $\operatorname{Pr}>|t|$ & & \\
\hline Intercept & 0.0154 & 0.1798 & 2 & 0.09 & 0.9396 & & \\
\hline Signed distance to ecotone & 0.003515 & 0.002477 & 52 & 1.42 & 0.1618 & & \\
\hline Signed distance to ecotone ${ }^{2}$ & 0.000081 & 0.00004 & 52 & 2.01 & 0.0501 & & \\
\hline \multicolumn{8}{|l|}{ ANT ASSEMBLAGE VARIABLES } \\
\hline Total ant abundance & & & & & & $\log$ & Normal \\
\hline Effect & Estimate & $S E$ & $D F$ & $t$ Value & $\operatorname{Pr}>|t|$ & & \\
\hline Intercept & 0.1828 & 0.1357 & 2 & 1.35 & 0.3102 & & \\
\hline Signed distance to ecotone & -0.00505 & 0.001875 & 230 & -2.69 & 0.0076 & & \\
\hline May & 1.6267 & 0.1306 & 230 & 12.45 & $<0.00001$ & & \\
\hline August & 1.4429 & 0.1306 & 230 & 11.05 & $<0.00001$ & & \\
\hline November & 0 & & & & & & \\
\hline February & 0.1715 & 0.1306 & 230 & 1.31 & 0.1906 & & \\
\hline Ant richness (pitfall scale) & & & & & & $\log$ & Poisson \\
\hline Effect & Estimate & SE & $D F$ & $t$ Value & $\operatorname{Pr}>|t|$ & & \\
\hline Intercept & -1.5581 & 0.2857 & 2 & -5.45 & 0.032 & & \\
\hline Signed distance to ecotone & -0.00363 & 0.001786 & 230 & -2.03 & 0.0432 & & \\
\hline May & 2.3909 & 0.2898 & 230 & 8.25 & $<0.00001$ & & \\
\hline August & 2.2713 & 0.2913 & 230 & 7.8 & $<0.00001$ & & \\
\hline November & 0 & & & & & & \\
\hline February & 0.7309 & 0.3376 & 230 & 1.31 & 0.0314 & & \\
\hline
\end{tabular}


Table S1 (continued).

\begin{tabular}{|c|c|c|c|c|c|c|c|}
\hline & & & & & & Link function & Error function \\
\hline \multicolumn{8}{|l|}{ ANT SPECIES ABUNDANCE } \\
\hline Aphaenogaster iberica (year round) & & & & & & Log & Normal \\
\hline Effect & Estimate & SE & $D F$ & $t$ Value & $\operatorname{Pr}>|t|$ & & \\
\hline Intercept & 0.1239 & 0.04614 & 2 & 2.68 & 0.1153 & & \\
\hline Signed distance to ecotone & -0.00307 & 0.001064 & 53 & -2.88 & 0.0057 & & \\
\hline \multicolumn{8}{|l|}{ Aphaenogaster iberica (spring) } \\
\hline Effect & Estimate & SE & $D F$ & $t$ Value & $\operatorname{Pr}>|t|$ & Log & Normal \\
\hline Intercept & 0.04235 & 0.02188 & 2 & 1.94 & 0.1925 & & \\
\hline \multirow{2}{*}{\multicolumn{8}{|c|}{ Aphaenogaster iberica (summer) }} \\
\hline & & & & & & & \\
\hline Effect & Estimate & SE & $D F$ & $t$ Value & $\operatorname{Pr}>|t|$ & Log & Normal \\
\hline Intercept & 0.09404 & 0.04093 & 2 & 2.3 & 0.1484 & & \\
\hline Signed distance to ecotone & -0.00255 & 0.000944 & 53 & -2.71 & 0.0091 & & \\
\hline \multicolumn{8}{|l|}{ Camponotus foreli (year round) } \\
\hline Effect & Estimate & $S E$ & $D F$ & $t$ Value & $\operatorname{Pr}>|t|$ & & \\
\hline Intercept & 0.2177 & 0.0493 & 2 & 4.42 & 0.0476 & Log & Normal \\
\hline Signed distance to ecotone & -0.00303 & 0.001083 & 53 & -2.8 & 0.0072 & & \\
\hline \multicolumn{8}{|l|}{ Camponotus foreli (summer) } \\
\hline Effect & Estimate & $S E$ & $D F$ & $t$ Value & $\operatorname{Pr}>|t|$ & Log & Normal \\
\hline Intercept & 0.1543 & 0.05477 & 2 & 2.82 & 0.1063 & & \\
\hline Signed distance to ecotone & -0.00105 & 0.001025 & 52 & -1.02 & 0.3121 & & \\
\hline Signed distance to ecotone ${ }^{2}$ & -0.00004 & 0.000018 & 52 & -2.07 & 0.0438 & & \\
\hline \multicolumn{6}{|c|}{ Camponotus sylvaticus (year round) } & Log & Normal \\
\hline Effect & Estimate & SE & $D F$ & $t$ Value & $\operatorname{Pr}>|t|$ & & \\
\hline Intercept & 0.1003 & 0.03736 & 2 & 2.69 & 0.1152 & & \\
\hline Signed distance to ecotone & -0.003 & 0.000861 & 53 & -3.49 & 0.001 & & \\
\hline \multicolumn{6}{|l|}{ Camponotus sylvaticus (spring) } & Log & Normal \\
\hline Effect & Estimate & $S E$ & $D F$ & $t$ Value & $\operatorname{Pr}>|t|$ & & \\
\hline Intercept & -0.03149 & 0.04515 & 2 & -0.7 & 0.5577 & & \\
\hline Signed distance to ecotone & -0.00115 & 0.000823 & 52 & -1.39 & 0.1694 & & \\
\hline Signed distance to ecotone ${ }^{2}$ & 0.000049 & 0.000018 & 52 & 2.75 & 0.0082 & & \\
\hline \multicolumn{6}{|l|}{ Goniomma blanci (year round) } & Log & Normal \\
\hline Effect & Estimate & $S E$ & $D F$ & $t$ Value & $\operatorname{Pr}>|\mathrm{t}|$ & & \\
\hline Intercept & 0.1873 & 0.06286 & 2 & 2.98 & 0.0966 & & \\
\hline \multirow{2}{*}{\multicolumn{6}{|c|}{ Goniomma blanci (spring) }} & & \\
\hline & & & & & & Log & Normal \\
\hline Effect & Estimate & $S E$ & $D F$ & $t$ Value & $\operatorname{Pr}>|\mathrm{t}|$ & & \\
\hline Intercept & 0.1759 & 0.06221 & 2 & 2.83 & 0.1056 & & \\
\hline \multirow{2}{*}{\multicolumn{6}{|c|}{ Plagiolepis schmitzii (summer) }} & & \\
\hline & & & & & & Log & Normal \\
\hline Effect & Estimate & $S E$ & $D F$ & $t$ Value & $\operatorname{Pr}>|\mathrm{t}|$ & & \\
\hline Intercept & 0.3315 & 0.06705 & 2 & 4.94 & 0.0386 & & \\
\hline Signed distance to ecotone & 0.003211 & 0.001541 & 53 & 2.08 & 0.0421 & & \\
\hline \multicolumn{6}{|l|}{ Temnothorax racovitzai (year round) } & Log & Normal \\
\hline Effect & Estimate & SE & $D F$ & $t$ Value & $\operatorname{Pr}>|\mathrm{t}|$ & & \\
\hline Intercept & 0.02044 & 0.01579 & 2 & 1.29 & 0.3249 & & \\
\hline Signed distance to ecotone & -0.00077 & 0.000364 & 53 & -2.11 & 0.0392 & & \\
\hline \multicolumn{6}{|l|}{ Temnothorax racovitzai (summer) } & Log & Normal \\
\hline Effect & Estimate & $S E$ & $D F$ & $t$ Value & $\operatorname{Pr}>|\mathrm{t}|$ & & \\
\hline Intercept & 0.02044 & 0.01579 & 2 & 1.29 & 0.3249 & & \\
\hline Signed distance to ecotone & -0.00077 & 0.000364 & 53 & -2.11 & 0.0392 & & \\
\hline \multicolumn{6}{|c|}{ Tetramorium semilaeve (year round) } & Log & Normal \\
\hline Effect & Estimate & $S E$ & $D F$ & $t$ Value & $\operatorname{Pr}>|t|$ & & \\
\hline Intercept & 0.1242 & 0.05274 & 2 & 2.35 & 0.1427 & & \\
\hline Signed distance to ecotone & -0.00151 & 0.000777 & 52 & -1.94 & 0.0579 & & \\
\hline Signed distance to ecotone ${ }^{2}$ & -0.00003 & 0.000016 & 52 & -2.15 & 0.0359 & & \\
\hline \multicolumn{6}{|l|}{ Tetramorium semilaeve (summer) } & Log & Normal \\
\hline Effect & Estimate & SE & $D F$ & $t$ Value & $\operatorname{Pr}>|\mathrm{t}|$ & & \\
\hline Intercept & 0.06498 & 0.04011 & 2 & 1.62 & 0.2466 & & \\
\hline Distecotono & 0.000093 & 0.000672 & 52 & 0.14 & 0.8899 & & \\
\hline Distecotono2 & -0.00002 & $9.36 \mathrm{E}-06$ & 52 & -2.36 & 0.022 & & \\
\hline
\end{tabular}


Table S2. Spearman's correlation coefficients and false discovery rate (FDR) between environmental variables and ant assemblage variables significantly changing between habitats. The threshold for FDR of Benjamini-Hochberg was set to 0.2 (see Methods). According this all the values of FDR < 0.2 are considered statistically significant. Cisclu - Cistus clusii; Fumthy - Fumana thymifolia; Pinhal - Pinus halepensis; Rosof - Rosmarinus officinalis; Stiten - Stipa tenacissima; Tab - Total abundance; Aphibe - Aphaenogaster iberica; Camfor - Camponotus foreli; Camsyl - Camponotus sylvaticus; Gonbla - Goniomma blanci; Plasch - Plagiolepis schmitzii; Temrac - Temnothorax racovitzai; Tetsem - Tetramorium semilaeve.

\begin{tabular}{|c|c|c|c|c|c|c|c|c|}
\hline Spearman's correlation coefficient & TAb_Y & TAb_Su & TAb_W & TAb_Sp & TAb_Au & Aphibe_Y & Aphibe_Su & Aphibe_Sp \\
\hline Chamaephytes & $-0 . \overline{08}$ & $-0 . \overline{0} 7$ & $0 . \overline{02}$ & -0.05 & $-0 . \overline{0} 5$ & -0.08 & $-0 . \overline{8}$ & $-0.0 \overline{5}$ \\
\hline Cisclu & -0.08 & -0.08 & -0.14 & -0.05 & -0.07 & -0.04 & -0.03 & -0.11 \\
\hline Perennial vegetation & 0.01 & 0.02 & 0.02 & -0.01 & -0.07 & 0.09 & 0.08 & 0.06 \\
\hline Fumthy & -0.05 & -0.02 & 0.11 & 0.04 & -0.02 & -0.11 & -0.07 & -0.07 \\
\hline Stones & 0.05 & 0.02 & -0.02 & 0.12 & 0.00 & 0.00 & -0.08 & 0.10 \\
\hline Pinhal & 0.07 & 0.07 & 0.02 & 0.15 & 0.05 & 0.03 & 0.04 & 0.20 \\
\hline Rocks & 0.07 & -0.03 & 0.04 & 0.08 & 0.04 & 0.08 & 0.08 & 0.09 \\
\hline Rosof & -0.07 & -0.07 & -0.10 & -0.06 & 0.03 & 0.10 & 0.09 & 0.12 \\
\hline Stiten & 0.02 & 0.02 & 0.07 & 0.00 & -0.06 & -0.03 & -0.03 & -0.01 \\
\hline Cover of soil & -0.05 & -0.05 & 0.08 & -0.14 & -0.11 & -0.03 & 0.06 & -0.14 \\
\hline FDR values & TAb_Y & TAb_Su & TAb_W & TAb_Sp & $\mathrm{TAb} A \mathrm{Au}$ & Aphibe_Y & Aphibe_Su & Aphibe_Sp \\
\hline Chamaephytes & 0.56 & 0.32 & 0.91 & 0.80 & 0.95 & 0.86 & 0.62 & 0.79 \\
\hline Cisclu & 0.44 & 0.45 & 0.91 & 0.80 & 0.95 & 0.88 & 0.80 & 0.79 \\
\hline Perennial vegetation & 0.92 & 0.89 & 0.91 & 0.98 & 0.95 & 0.86 & 0.62 & 0.79 \\
\hline Fumthy & 0.82 & 0.06 & 0.91 & 0.88 & 0.95 & 0.86 & 0.62 & 0.79 \\
\hline Stones & 0.17 & 0.06 & 0.91 & 0.80 & 0.98 & 1.00 & 0.62 & 0.79 \\
\hline Pinhal & 0.33 & 0.58 & 0.91 & 0.80 & 0.95 & 0.10 & 0.10 & 0.79 \\
\hline Rocks & 0.56 & 0.89 & 0.91 & 0.80 & 0.16 & 0.86 & 0.62 & 0.79 \\
\hline Rosof & 0.56 & 0.45 & 0.91 & 0.80 & 0.95 & 0.86 & 0.62 & 0.79 \\
\hline Stiten & 0.90 & 0.89 & 0.91 & 0.98 & 0.95 & 0.88 & 0.80 & 0.92 \\
\hline Cover of soil & 0.17 & 0.18 & 0.91 & 0.80 & 0.59 & 0.88 & 0.80 & 0.79 \\
\hline Spearman's correlation coefficient & Camfor_Y & Camfor_Su & Camfor_sp & Camsyl_Y & Camsyl_Sp & Gonbla_Y & Gonbla_Sp & Plasmi_Su \\
\hline Chamaephytes & -0.06 & 0.03 & -0.09 & -0.05 & -0.06 & 0.04 & 0.07 & 0.07 \\
\hline Cisclu & -0.05 & -0.09 & -0.05 & -0.06 & -0.06 & -0.02 & 0.01 & -0.07 \\
\hline Perennial vegetation & -0.08 & -0.09 & -0.03 & -0.06 & -0.04 & 0.04 & 0.06 & -0.02 \\
\hline Fumthy & -0.11 & -0.08 & -0.08 & -0.05 & -0.05 & 0.00 & 0.00 & -0.02 \\
\hline Stones & 0.06 & 0.10 & 0.05 & 0.06 & 0.05 & -0.06 & -0.07 & 0.04 \\
\hline Pinhal & 0.06 & 0.08 & 0.06 & 0.06 & 0.05 & -0.06 & -0.06 & -0.07 \\
\hline Rocks & 0.05 & -0.04 & 0.05 & 0.06 & 0.04 & -0.04 & -0.06 & -0.07 \\
\hline Rosof & -0.01 & -0.11 & 0.07 & -0.05 & -0.05 & -0.06 & -0.06 & -0.07 \\
\hline Stiten & -0.10 & -0.07 & -0.06 & -0.05 & -0.05 & 0.06 & 0.07 & 0.06 \\
\hline Cover of soil & -0.09 & -0.06 & -0.08 & -0.06 & -0.05 & 0.05 & 0.06 & 0.05 \\
\hline FDR values & Camfor_Y & Camfor_Su & Camfor_Sp & Camsyl_Y & Camsyl_Sp & Gonbla_Y & Gonbla_Sp & Plasmi_Su \\
\hline Chamaephytes & 0.65 & 0.85 & 0.48 & 0.57 & 0.30 & 0.14 & 0.28 & 0.47 \\
\hline Cisclu & 0.17 & 0.68 & 0.19 & 0.31 & 0.42 & 0.86 & 0.90 & 0.56 \\
\hline Perennial vegetation & 0.63 & 0.68 & 0.84 & 0.21 & 0.17 & 0.74 & 0.54 & 0.87 \\
\hline Fumthy & 0.52 & 0.68 & 0.48 & 0.41 & 0.54 & 0.00 & 0.00 & 0.87 \\
\hline Stones & 0.65 & 0.68 & 0.76 & 0.38 & 0.50 & 0.22 & 0.28 & 0.87 \\
\hline Pinhal & 0.17 & 0.68 & 0.19 & 0.31 & 0.26 & 0.26 & 0.33 & 0.34 \\
\hline Rocks & 0.65 & 0.85 & 0.76 & 0.31 & 0.17 & 0.74 & 0.54 & 0.22 \\
\hline Rosof & 0.94 & 0.68 & 0.76 & 0.41 & 0.30 & 0.65 & 0.54 & 0.27 \\
\hline Stiten & 0.63 & 0.68 & 0.76 & 0.22 & 0.50 & 0.65 & 0.43 & 0.72 \\
\hline Cover of soil & 0.63 & 0.68 & 0.48 & 0.21 & 0.17 & 0.26 & 0.29 & 0.72 \\
\hline Spearman's correlation coefficient & Richness_Su & Richness_Wi & Richness_Sp & Richness Au & Richness_Y & Temrac_Y & Temrac Su & Tetsem_Y \\
\hline Chamaephytes & -0.09 & 0.02 & -0.08 & -0.04 & -0.06 & -0.07 & -0.07 & 0.01 \\
\hline Cisclu & -0.10 & -0.14 & -0.06 & -0.07 & -0.03 & -0.08 & -0.08 & 0.00 \\
\hline Perennial vegetation & 0.04 & -0.01 & 0.01 & -0.06 & -0.05 & 0.06 & 0.06 & -0.10 \\
\hline Fumthy & -0.04 & 0.07 & 0.01 & -0.03 & -0.07 & -0.04 & -0.04 & -0.07 \\
\hline Stones & 0.04 & 0.04 & 0.07 & -0.01 & 0.02 & 0.06 & 0.06 & 0.09 \\
\hline Pinhal & 0.04 & 0.04 & 0.04 & 0.05 & 0.00 & 0.03 & 0.03 & 0.09 \\
\hline Rocks & -0.04 & 0.07 & 0.07 & 0.04 & 0.05 & 0.08 & 0.08 & 0.10 \\
\hline Rosof & -0.07 & -0.09 & 0.06 & 0.03 & 0.03 & 0.06 & 0.06 & 0.08 \\
\hline Stiten & -0.01 & 0.03 & -0.05 & -0.05 & -0.07 & -0.02 & -0.02 & -0.13 \\
\hline Cover of soil & -0.07 & 0.03 & -0.06 & -0.11 & -0.01 & -0.07 & -0.07 & -0.09 \\
\hline FDR values & Richness_Su & Richness_Wi & Richness_Sp & Richness_Au & Richness_Y & Temrac_Y & Temrac_Su & Tetsem_Y \\
\hline Chamaephytes & 0.68 & 0.92 & 0.70 & 0.91 & 0.55 & 0.52 & 0.52 & 0.97 \\
\hline Cisclu & 0.62 & 0.92 & 0.28 & 0.91 & 0.11 & 0.45 & 0.45 & 0.97 \\
\hline Perennial vegetation & 0.99 & 0.96 & 0.98 & 0.91 & 0.67 & 0.52 & 0.52 & 0.69 \\
\hline Fumthy & 0.14 & 0.92 & 0.98 & 0.91 & 0.49 & 0.69 & 0.69 & 0.69 \\
\hline Stones & 0.14 & 0.92 & 0.70 & 0.94 & 0.05 & 0.52 & 0.52 & 0.37 \\
\hline Pinhal & 0.14 & 0.92 & 0.10 & 0.91 & 0.01 & 0.10 & 0.10 & 0.69 \\
\hline Rocks & 0.99 & 0.92 & 0.28 & 0.14 & 0.21 & 0.42 & 0.42 & 0.69 \\
\hline Rosof & 0.91 & 0.92 & 0.78 & 0.91 & 0.77 & 0.27 & 0.27 & 0.69 \\
\hline Stiten & 0.99 & 0.92 & 0.84 & 0.91 & 0.49 & 0.84 & 0.84 & 0.65 \\
\hline Cover of soil & 0.29 & 0.92 & 0.28 & 0.60 & 0.04 & 0.48 & 0.48 & 0.37 \\
\hline Spearman's correlation coefficient & Tetsem Su & & & & & & & \\
\hline Chamaephytes & 0.04 & & & & & & & \\
\hline Cisclu & -0.02 & & & & & & & \\
\hline Perennial vegetation & -0.07 & & & & & & & \\
\hline Fumthy & -0.05 & & & & & & & \\
\hline Stones & 0.18 & & & & & & & \\
\hline Pinhal & 0.02 & & & & & & & \\
\hline Rocks & -0.05 & & & & & & & \\
\hline Rosof & 0.06 & & & & & & & \\
\hline Stiten & -0.13 & & & & & & & \\
\hline Cover of soil & -0.12 & & & & & & & \\
\hline FDR values & Tetsem_Su & & & & & & & \\
\hline Chamaephytes & 0.85 & & & & & & & \\
\hline Cisclu & 0.86 & & & & & & & \\
\hline Perennial vegetation & 0.83 & & & & & & & \\
\hline Fumthy & 0.83 & & & & & & & \\
\hline Stones & 0.83 & & & & & & & \\
\hline Pinhal & 0.86 & & & & & & & \\
\hline Rocks & 0.83 & & & & & & & \\
\hline Rosof & 0.83 & & & & & & & \\
\hline Stiten & 0.83 & & & & & & & \\
\hline Cover of soil & 0.83 & & & & & & & \\
\hline
\end{tabular}


Shift

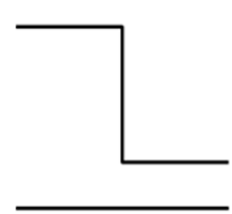

Grassland $\longrightarrow$ Reforestatio

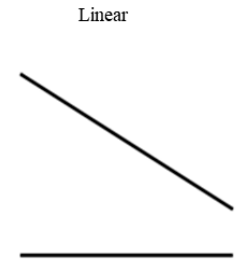

Grassland $\longrightarrow$ Reforestatio

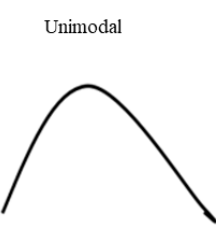

Grassland $\longrightarrow$ Reforestatio

Fig. S1. Possible models of response of a variable to the ecotone and/or changes between habitats.

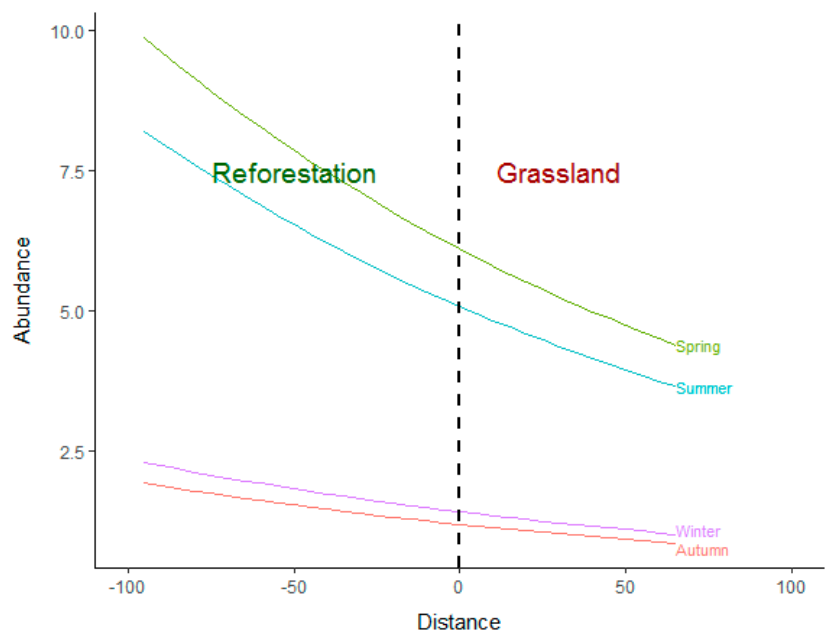

Fig. S2. Total ant abundance. Expected values from models on Table S1.
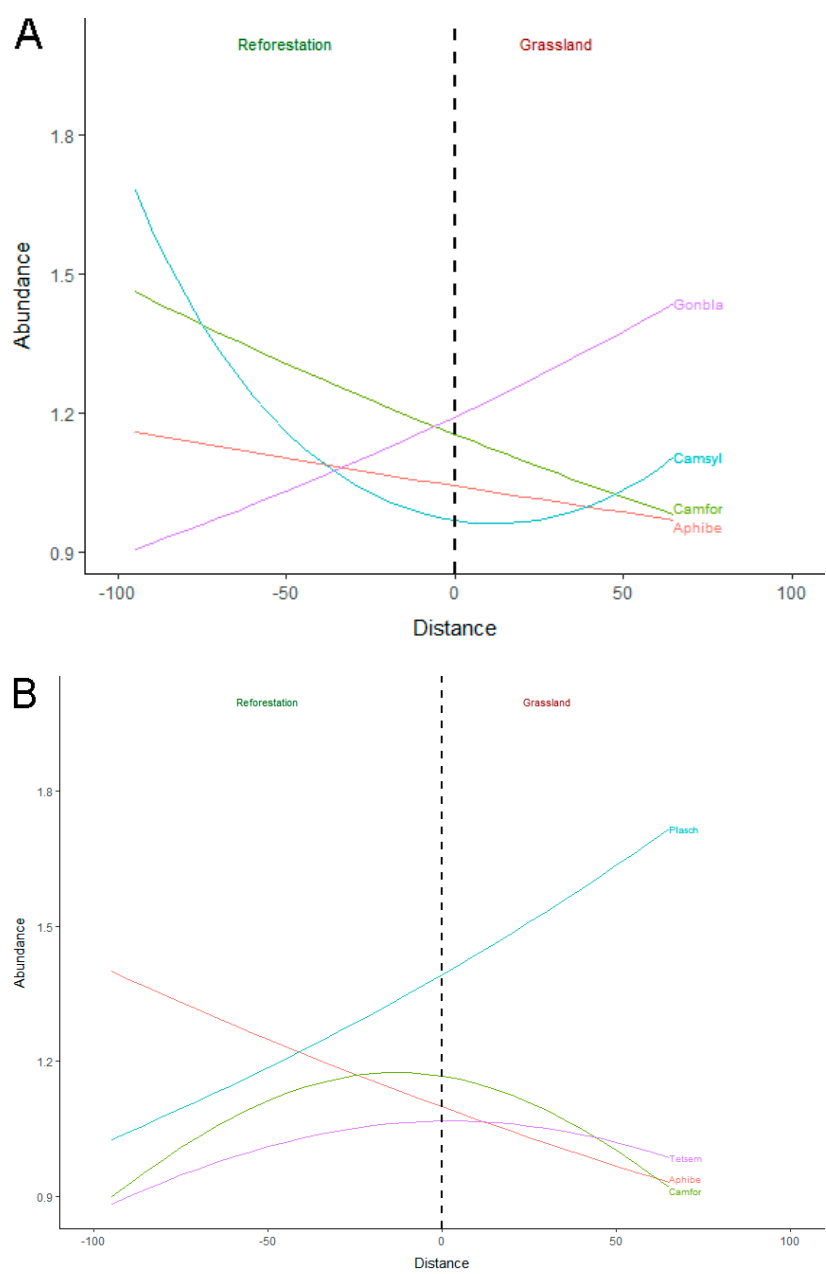

Fig. S3. Ant species abundance. Expected values from models on Table S1. A - spring; B - summer. Aphibe - Aphaenogaster iberica; Camfor - Camponotus foreli; Camsyl - Camponotus sylvaticus; Gonbla - Goniomma blanci; Plasch - Plagiolepis schmitzii; Tetsem - Tetramorium semilaeve. 